Barber, T. (2017) 'Achieving ethnic authenticity through 'return' visits to Vietnam: paradoxes of class and gender among the British-born Vietnamese', Journal of Ethnic and Migration Studies, 43 (6), pp. 919-936.

DOI: https://doi.org/10.1080/1369183X.2016.1274564

This document is the authors' Accepted Manuscript.

License: https://creativecommons.org/licenses/by-nc-nd/4.0

Available from RADAR: https://radar.brookes.ac.uk/radar/items/e0de1b0a-89c7-4690-9ed8-1bd56ccfc045/1/

Copyright $(\subset$ and Moral Rights are retained by the author(s) and/ or other copyright owners unless otherwise waived in a license stated or linked to above. A copy can be downloaded for personal non-commercial research or study, without prior permission or charge. This item cannot be reproduced or quoted extensively from without first obtaining permission in writing from the copyright holder(s). The content must not be changed in any way or sold commercially in any format or medium without the formal permission of the copyright holders. 


\title{
Achieving ethnic authenticity through 'return' visits to Vietnam: paradoxes of class and gender among the British-born Vietnamese
}

\begin{abstract}
The Vietnamese in Britain are a small and less visible community who remain largely unrecognised in wider society. For those born in Britain, constructing a Vietnamese identity and a sense of ethnic belonging is often rendered problematic due to a lack of inclusion in, and identification with, their local Vietnamese community. Instead, 'return' visits to Vietnam occupy a particularly important space in their narratives of ethnic authentification. Drawing upon the literature on migrant-homeland relations, this paper highlights the importance of divisions of gender, class and migration trajectories in understanding patterns of transnational participation and engagement among Vietnamese migrants. It is argued that British-born Vietnamese women are more likely to engage actively in their 'return' visits and make personal and emotional investments compared to their male counterparts whose visits remain largely symbolic. These differences are shaped by social class configurations and gender expectations both in Britain and Vietnam. However, while 'return' visits provide more effective ethnic authentification strategies for women than men who experience a more compromised masculine status and negative experiences in the 'homeland', paradoxically their class differences with the majority of the population weakens and questions this authenticity leading to an 'arrested' achievement of ethnic authenticity.
\end{abstract}

Keywords: 'Return’ visits, British-born Vietnamese, ethnic authenticity, transnationalism 


\section{Introduction}

Scholarship on transnationalism has richly documented the relationships between migrants and their homeland revealing a plethora of ways in which migrants live transnational lives that have transformatory effects upon both in their homelands and host societies. For example, Levitt (2001) has shown how Dominicans in Boston develop powerful familial, religious, and political connections between the Dominican Republic, and Boston as ties that transform life in both the home and host country. Likewise, Eckstein (2009) has revealed how the so called New Cubans in America (although poor and politically weak), have been more successful than the earlier prosperous exiles in transforming the Cuban regime through an unintended consequence of their personal ties maintain with family in Cuba. Important political and economic contributions to the homeland have also been illustrated in the work of Iskander (2010) and Smith (2005) in relation to first-generation Moroccan and Mexican migrants. Such studies highlight how transnationalization and assimilation act as interrelated rather than opposing processes and are strongly inflected by processes of social class, generation and gender.

In the Vietnamese Diaspora, transnational practices including sending remittances, marriage migration and return visits have been identified in the US (Thai 2008, 2011, 2014, Espiritu and Tran 2002, Kibria 1997), Australia (Thomas 2003, Carruthers 2002, 2008, 2013) and Southeast Asia (Belanger 2011, Chan 2013, Chan and Wu 2011). In the US, Thai (2014) has shown how low-wage American Vietnamese migrants return to Vietnam to improve their social status through a more favourable positioning in so called the 'transnational expenditure cascade'. Using the notion of 'return visits as global magnified moments', Thai (2014) shows how return visits can elicit enormous emotions and a strong sense of belonging to the homeland and transforming the social construction of gender and social class in transnational contexts. Focusing on the second-generation, Espiritu and Tran (2002) show how 'symbolic 
transnationalism' takes place among young Vietnamese Americans who engage symbolically with the homeland through the transnational flow of ideas, norms and values and also 'imagined returns to the homeland through selective memory, cultural rediscovery and sentimental longings' $(2002 ; 369)$. Return migration to Vietnam from the international diaspora has been an increasing trend in recent years (Carruthers 2002, Chan and Tran 2011, Chan 2013, Thai 2011, 2013, 2014). Over the last two decades the relaxation of Vietnamese Government Policy towards the Viet Kieu (Overseas Vietnamese) on visa requirements to enter the country, their ability to invest in business and send money to Vietnam, and travel between provinces once in Vietnam, has contributed to this increasing return migration (Phuong 2000, Chan 2011 and Pham 2010). Chan and Tran (2011) have examined the interactive dynamics between the homeland society and the returning migrants, from the US, Canada, Germany, Hong Kong, to show how changes occur both to the migrants' identity and to the state and society of origin.

In Britain, transnational practices among the Vietnamese have been identified mainly among the first-generation. For example, James (2011) has explored how transnational relations of the first-generation Vietnamese in London extend across Europe. Likewise, Bagwell $(2008,2015)$ has identified the different transnational practices adopted by Vietnamese businesses as strategies for sustaining otherwise fragile forms of entrepreneurship in Britain. However, as yet, little attention has been paid to the role of transnationalism in the lives of the British-born population, nor how processes of gender and social class processes shape their transnational activities.

In this paper, the concepts of 'return visits as global magnified moments' (Thai 2011) and 'symbolic transnationalism' (Espiritu and Tran 2002) will be used to explore the ways in which young British-born Vietnamese engage in transnational spaces of belonging. While Thai uses 'return visits as global magnified moments' to refer to specific gendered social 
class transformations, I will use the term to refer to magnified moments of ethnic authentification and belonging which transform relations to the homeland and the diaspora community, and are shaped by particular gender and social class processes.

Given the confines of the British Vietnamese community, many young people looked elsewhere to the international diaspora to develop connections, relationships and ties. It is argued that the British-born Vietnamese participants' sense of inclusion in the London Vietnamese community seems to be highly contingent upon their positioning along a number of axes of difference relating to ethnic origin, generation, and ideological and geographical origins in Vietnam. This compels the young British-born Vietnamese to navigate a complicated terrain as the boundaries of belonging are drawn differently across different sections of the wider community; thus restricting the development of an imagined community among the British-born Vietnamese in London. It is suggested that return visits (in actual and symbolic forms) provide a form of 'diasporic cultural capital' used by the British-born Vietnamese to claim a stronger sense of belonging and ethnic authenticity in London.

While there are tensions and differences between the concepts of diaspora and transnationalism with the former tending to represent aspects of identity and belonging and the latter referring more to non-politicised forms of transactions and reciprocity and the maintenance of kinship ties (see Faist 2010, Johnson 2012). This article will use the concept of diaspora to refer to identity and imagined community, while the use of transnational practices will refer to return visits home as a transnational border activity. This article will explore how visits to Vietnam provide ethnic authentification strategies for the British-born Vietnamese. However, the degree to which these strategies are used depends upon specific gender and social class configurations. A paradox is noted whereby ethnic authenticity is achieved via return visits but their social class differences with the majority of the population challenges this authenticity, leading to an arrested achievement of ethnic authenticity. The 
paper will begin by providing a context of the Vietnamese diaspora in Britain. A brief review of approaches to transnationalism and 'return' visits among the second-generation and the role of social class and gender in these processes will be undertaken before moving on to explore the role of transnational practices in constructing ethnic authenticity in narrative accounts of British-born Vietnamese.

\section{The Vietnamese diaspora in Britain}

The Vietnamese are a numerically small minority in Britain counting 60,635 ${ }^{1}$ in the 2011 census (ONS 2011), with those born in Britain estimated at 22,000 in 2006 (IOM 2006). Compared to the major Vietnamese diaspora communities in the US, Canada, Australia and France - which were initially composed of South Vietnamese fleeing Vietnam after the fall of Saigon in 1975 - the majority of refugees arriving in Britain were from North Vietnam $(62 \%)$, largely ethnic-Chinese fleeing persecution after the Chinese invasion of Vietnam in 1979 (Dalglish 1989, Duke and Marshall 1995). Today the community in Britain can be understood as being composed of four main social groups which correspond to initial migratory trajectories. The first (and smallest) group are refugees (and their descendants) from the former state of South Vietnam during the 1970s. The Second, (and largest) group, are refugees (and descendants) from North Vietnam who arrived during the late 1970s/early 1980s, fleeing the Chinese invasion of Vietnam in 1977. The third group are, new economic migrants from North Vietnam (1990s onwards), and the fourth, international students (from early 2000s). The gender composition of these groups is believed to display broadly equal numbers of men and women (IOM2006).

Contemporary configurations of the 'Vietnamese community' in Britain indicate that these social divisions still exist ${ }^{2}$. Notably, the North Vietnamese have tended to have more contact with Vietnam in recent years due to their less problematic positioning in relation to 
the Vietnamese government as economic migrants, while the South Vietnamese tended to have more contacts in the international diaspora including a range of transnational organizations and networks due to their more critical stance towards the Vietnamese government as also found elsewhere in the diaspora (Viviani 1997, Lieu 2011). This has had certain implications for those born in Britain; notably, the children of North Vietnamese parents, had more contact with the London community and these young people often recounted a more acute sense of exclusion and lack of belonging due to their limited connection to and knowledge of Vietnam including; limited access to the cultural heritage and language, meanwhile those from South Vietnamese families tended to have a more politicized identity and looked to international (anti-communist) diaspora organizations in the US and Australia and France (Barber 2015). A lack of belonging in the London community has been found to inhibit ethnic identity formation. For example, a study by Sims (2007) found young British-born Vietnamese expressed concerns over not being able to meet the 'expectations' of the Vietnamese community and felt of 'inadequate' in their knowledge of Vietnamese culture which led to a 'lack of engagement' and a 'lack of legitimacy' to participate in the community which contributed to a sense of being 'lost' or 'unrooted' in their cultural heritage. The British-born Vietnamese have also described not 'feeling' Vietnamese because a deeper cultural sense of being Vietnamese and a sense of a collective Vietnamese identity and belonging were missing in the community (Sims 2007, Barber 2015).

The Vietnamese like other East and Southeast Asians in Britain, including the more established British Chinese population, have also tended to remain 'silent' minorities who rarely feature in debates on British multiculturalism and remain invisible in public debates about racism (Barber 2015, Parker 1995, 2000). Such experiences have been identified elsewhere as encouraging practices of transnationalism, as forms of exclusion in the host 
country often lead individuals to seek out meaning and belonging in ancestral lands (Delaney 1990, Cohen 1979).

\section{'Second-generation' transnationalism: gender, social class and authenticity}

While forms of transnationalism among the second-generation ${ }^{3}$ are likely to be different to the first-generation in terms of attachment, engagement and the frequency and intensity of these in relation to the homeland (Kasinitz et al 2008), an increasing range of studies have shown how the second-generation forge active relationships with their 'homeland' in a number of different ways (Levitt and Waters 2002). Levitt (2009) argues that being raised in a 'transnational social field' can have a powerful influence upon the second-generation with respects to their socialisation of norms and values, practices and the know-how of ancestral homes and shows how this may come to the fore at different stages across the life-course. As noted by Fresnoza-Flot and Shinozaki (forthcoming), creating and operating in 'transnational social spaces' leads migrants to 'interpret differently their experiences', giving rise to the formation of 'transnational frames of reference' (15). In this article, being raised in a transnational social field comes to the fore for young British-born Vietnamese who have entered early adulthood and are able to make personal decisions about their relationship to the 'homeland' and often have the financial capabilities to fund their visits to Vietnam.

Gender is another important social division which also shapes how the secondgeneration engage transnationally. For example, in the host country, gender difference might be reinforced and reinvented to create hierarchies that are even more rigid and 'traditional' than in the homeland (Alumkal 1999; Caglar 1995; Espiritu 1992). While at the same time, transnationalism can put women in a dilemma between the gender equality of Western society and their often more inferior position in the country of origin (Ong 1999). Likewise, 
in terms of social class, migrants often have to negotiate conflicting socio-economic and racial stratifications systems (Levitt 2009). This might mean that they become more socially mobile in one country while experiencing downward social mobility in another, as exemplified by Thai (2014). Transnationalism may be experienced differently according to social class, for example, Pluss (2005) and Raj (2003) have shown how middle-class and professional migrants have sufficient social and cultural capital to more selectively assimilate elements of where they come from and where they settle. However, the picture is also often more complicated than this, and Fresnoza-Flot and Shinozaki (forthcoming) caution over the tendency to collapse a wider range of class issues into economic ones but instead take account of the full range of dimensions of class as a lived experience (including moral, symbolic, cultural, etc.) and assess how these work alongside gender and generation in the transnational field. Kasinitz et al (2008) have shown how transnational practices also vary by group according to geographic distance between the home and host countries, homeland politics and the frequency of visiting and sending remittances.

The practice of 'return migration' and 'return visits' can be particularly important for the forging of ethnic identity and belonging among migrants (Cohen 1997, Duval 2004). Christou (2006) and King and Christou (2010) show how 'second-generation return' is an important feature in the Greek diaspora for building a sense of ethnic belonging. Other studies have also referred to the concept of 'roots tourism' to discuss the range of ways in which various diaspora members engage in, and experience, their 'return' to the homeland (Basu 2004, Maruyama and Stronza 2010, Kibria 2002, Louie 2003, Delaney 1990, Cohen 1974). However, the issue of 'return' in relation to the second-generation maybe considered somewhat of an oxymoron as most of this generation may never been to their ancestral land and it will often the first time they have paid a visit. In the context of this study, I will refer to these experiences as simply 'visits' to Vietnam as the participants did not necessarily refer to 
Vietnam as 'home'. However, while most British-born Vietnamese did not necessarily think of Vietnam as 'home', Vietnam and the national Vietnamese still loom large in their consciousness of ethnic authenticity. As Carruthers $(2002 ; 429)$ has noted in relation to the Australian Vietnamese "the national community [...] retains a monopology over the right to define who or what is authentically Vietnamese'. This trend has also been identified among second-generation Vietnamese Americans by Espiritu and Tran (2002) who found that the ethnic authenticity of was often challenged by older members of the community. Espiritu and Tran (2002) refer to questions of 'ethnic authenticity' among the younger generation, perceived as the ability to understand homeland dynamics and culture as well as their competence in Vietnamese language and other understandings of the culture including gender roles and family values. I will also use the term 'ethnic authenticity' to indicate value judgments made between members of the community on the basis of the ability to belong as Vietnamese as well as issues of possessing cultural competence.

In this article, social class will be understood in both symbolic terms (Bourdieu 1983) and also in a Weberian sense (1946) to account for a form of diasporic cultural/symbolic capital among the British-born Vietnamese (for example, the material wealth in terms of money available to travel to Vietnam as well as that given to family) as well as more intangible forms of social status which diasporic subjects use to as a form of agency to navigate transnational fields - in the sense of Levitt and Glick Schiller (2004). Erel (2009) has referred to the term 'migration-specific cultural capital' to explain the ways in which migrant women challenge and transform existing classificatory systems of cultural validation (647). In this article, diasporic cultural capital will refer to the specific diasporic field within which certain cultural resources (language skills, knowledge of Vietnamese culture) can be converted into other forms of capital (such as social acceptability and status in the London Vietnamese community). 


\section{Methodology}

This article draws upon interview data taken from a broader study on experiences of identity and belonging among young British-born Vietnamese men and women in London. Primary research interviews and participant observation were conducted between July 2005 and February 2009. Participants between the ages of 17 and 34 years were interviewed with a gender composition of 16 men and 12 women ${ }^{4}$. The research used open-ended biographical narrative interviews adapted from Biographical Narrative Interpretive Method (BNIM) (Wengraf 2001), and focused upon the participant's biographical experiences of being Vietnamese in Britain. The participants came from a range of social backgrounds, including both North and South Vietnamese families and a range of socio-economic and occupational backgrounds. Most participants identified as Vietnamese and some identified as ChineseVietnamese. All participants were born in the UK and all were educated in the UK and used English as their primary language. Their parents had migrated to the UK in different migration waves between the late 1970s and 1980s as both political refugees and economic migrants from Vietnam, eventually gravitating to London.

Transnational experiences and practices were discussed in 25 of the 28 interviews and were raised by participants in relation to issues of ethnic identity and belonging within the Vietnamese community ${ }^{5}$. Visits to Vietnam, in particular, often functioned as an 'interpretive resource' which was drawn upon to enable participants to place themselves in relation to other Vietnamese and act as a barometer of their acceptance or 'authenticity'. As a white, female researcher who was positioned as an 'outsider', I was often given frank and detailed descriptions of the dynamics of the Vietnamese community in London and abroad. As I was perceived as far removed from their context certain detailed nuances about local community 
relations were divulged that might not have been, had I been part of the community; although undoubtedly being an outsider will have precluded the discussion of other ethnic phenomena. Findings presented in this article do not claim to represent the experience of all British-born Vietnamese but rather they provide a flavour and insight into how some of the young Britishborn Vietnamese have engaged in transnational activities as part of their broader narratives and construction of their Vietnamese identity and belonging. While wider participation in transnational organizations and transnational activities involving communities in the international Vietnamese diaspora also featured among the transnational practices of the British-born Vietnamese, for clarity and given the remit and scope of this article visits to Vietnam are the main practice explored here.

\section{Validating ethnic authenticity and belonging through visits to Vietnam}

Due to the barriers to community engagement, experienced at the local level (illustrated above) Vietnamese participants often turned to the international diaspora to develop connections, relationships and ties in order to build a sense of ethnic belonging as well as to explore their cultural heritage. This was achieved in different ways by participants and patterns of social class and gender were evident in shaping these transnational activities. Notably, South Vietnamese participants often drew upon existing transnational links with coethnics from other countries in the international Vietnamese diaspora (these were often drawn upon by those from middle-class professional backgrounds), while North Vietnamese participants engaged in activities such as sending remittances, participating in ethnic niche economy networks in the international diaspora as well as forming trans-ethnic spaces of belonging in London (see Barber 2015, for a full discussion). Visits to Vietnam were also engaged in differently by men and women ranging from more temporal investments including 
short 'tourist visits' to more sustained investments including prolonged trips to teach English or to work and even set up businesses.

Visits to Vietnam acted as 'magnified moments'(Thai 2011) for ethnic authentification as they often provided the first chance for the British-born to explore their Vietnamese ethnicity including developing their own sense of feeling 'at home' and as being accepted in Vietnam. In the remaining sections of this article, the narratives of Vietnamese men and women are explored to illustrate how gender, social class and North/South backgrounds shape and at times inhibit participation in, and making investments (both personal and emotional) in, Vietnam.

\section{British-born Vietnamese women's narratives of visits to Vietnam}

Among British-born Vietnamese women, visits to Vietnam were narrated as concerted efforts to invest personally in Vietnam and Vietnamese culture and language. North Vietnamese women in particular narrated more personalized and emotional experiences of visiting Vietnam which often served as magnified moments in their ethnic identity construction. These were partly shaped by their broader family involvement with Vietnam and expectations of them during their visits. An evolving sense of Vietnamese authenticity and belonging in Vietnam is illustrated by Mary following her marriage to a first-generation Vietnamese man in London:

'The first time when I came back [to Vietnam] was when I got married ... I was more English, I didn't know a lot about the Vietnamese community. The second time when I went, I thought, OK, I like it, I'm getting used to that. When I came back this year, I realised I was really enjoying the Vietnamese community in Vietnam because you got 
to know places, had eaten the food, got to know people, you know in conversation, and to be honest they were quite impressed with that because I have lived here [London] all my life and to speak fluent Vietnamese, they were all quite shocked. Not a lot of people that have lived here [London] can speak good Vietnamese!'

(Mary, 27, North Vietnamese, East London)

Mary explains a 'magnified moment' where she earned acceptance and gained familiarity among the Vietnamese in Vietnam, who are positioned as the arbiter of Vietnamese authenticity ${ }^{6}$. Through her visits to Vietnam she appears to have moved from a more 'English' cultural identity to a Vietnamese one, by achieving the status of an authentic Vietnamese woman, through acculturation in Vietnam and fluency in Vietnamese language. Such processes and experiences were commonly narrated among North Vietnamese women as a way to overcome a lack of belonging and acceptance in the local Vietnamese community in London. The same process was also articulated by other North Vietnamese female participants who experienced a similar transformation in their own sense of ethnic authentication in Vietnam. Another example of this is described by Rachel who spent her 'gap-year' working in Vietnam:

I hadn't been back to Vietnam for that long, so I decided to go back for longer and just meet family and everything again and get to know Vietnam more. When I was there I had language lessons once a week for quite a few months and I also helped in an orphanage. I didn't really do much, I should have done more in that year but I guess I just enjoyed it there cos I learnt a lot more about Vietnam after that trip, I felt really much more Vietnamese, I understand more about how people live. Before that I did feel Vietnamese but I just felt more like I was just a Vietnamese British person, 
but when I went to Vietnam felt that I could integrate more with people there and understand them. When I came back here, I met people who had like not lived in Britain all of their lives but who had recently come from Vietnam, I could understand them much more. From that time onwards, I have always wanted to go back every year. I am in more of a direction to work in Vietnam in the future and like have more to do with Vietnam.

For Rachel, going to Vietnam strengthened her sense of Vietnameseness both in Britain and in Vietnam, as well as forging an ongoing relationship with Vietnam. Rachel's decision to live in Vietnam for a year was based on wanting to get to know Vietnamese culture and language driven by a sense of feeling excluded in her local Vietnamese community in London. Rachel's sense of Vietnamese authenticity was deepened by her experiences of acceptance in the local neighbourhood in North Vietnam ${ }^{7}$, as further illustrated below:

It was just like when you were on the streets and everything, instead of being like a tourist when you are walking around, I just felt like I was looking at other people, them being tourists themselves and I would feel like part of Vietnam rather than being a Western person in Vietnam. I started feeling 'ahh look a Westerner'- sort of thing. I was like outside looking in again or kind of reverse and they [local Vietnamese] were like 'oh, OK she is just like one of us really'. I know a lot of people my age and they go back and it is like a holiday for them really, but I don't really see it like a holiday, I see it now like I am going home, kind of another home I have, I really do feel like home from London instead of being a holiday.'

(Rachel, MSc student, North Vietnamese, East London) 
Here Rachel seems to counter-position herself against other Viet Kieu whom might be understood as undertaking a form of more superficial 'roots tourism' (Basu 2004). For Rachel, being accepted as 'one of us' provides a powerful sense of inclusion and belonging as an 'authentic' Vietnamese person in Vietnam and empowers her to maintain contacts in Vietnam and return to visit regularly. Such links become an important backdrop against which to construct a Vietnamese identity in Britain, as they provide an alternative 'homefrom-home' to belong ethnically as Vietnamese, which could not be found in Britain. Transnational relations built upon repeated visits here can be seen to transform ties both to the 'homeland' and the host society (Levitt and Glick Schiller 2004). In Rachel's case 'passing' as a local Vietnamese is seen as a verification of her ethnic authenticity. In contrast, other research has shown how the Viet Kieu returnees are often easily identifiable by the local population (Chan and Tran 2011; Carruthers 2002), because they are seen as 'fatter' (Carruthers 2002), and also fairer skinned.

While not all of the British-born Vietnamese women had actually visited Vietnam, the prospect of returning to Vietnam acted as a form of symbolic transnationalism (also see Espiritu and Tran 2002). For example, Jenny, prompted by her father, has future plans to visit Vietnam to 'give something back to Vietnam' by using her skills in journalism to work in a Vietnamese publishing company:

I'm thinking about going to Vietnam and being part of that community. Recently, I thought, well, it would be nice to do something in Vietnam. So that is one of the big reasons why I want to move to Vietnam, I want to be able to work on a paper or magazine, and if that fails then I will definitely think about doing something over here and helping out the community over here. I shouldn't be saying if I don't do it over 
there - I should probably be doing it [here] anyway - but it is probably sheer laziness (laughs) but I do think about it.

(Jenny, 29, Magazine Editor, North Vietnamese, North London)

Having struggled to connect with local Vietnamese networks in London (due to a lack of Vietnamese language skills) the prospect of future 'return' to Vietnam enables Jenny to envisage re-engaging with the broader Vietnamese community, on her own terms and in a way that is productive for her career development. The need to reconnect with the 'homeland' in order to engage with the local community as a bona fide member seems particularly pertinent, as it alludes to the greater power of homeland (rather than diaspora) connections to reinvigorate ethnicity (Caruthers 2013). The desire among younger generations to 'help' Vietnam has been argued by Espiritu and Tran (2002) as evidence of the 'symbolic hold' that Vietnam has over the immigrant second generation. Here, the prospect of working in Vietnam seems eminently more appealing than working in the London community as a route to 'affirm[ing] the ethnic self' (Espiritu and Tran 2002; 389).

In the examples above, women narrate their visits to Vietnam in a way that is empowering to their sense of 'roots' which have been largely stripped away in the London community. By providing concrete reasons to visit to Vietnam such as meeting family, for marriage purposes, and to return for work to 'help out' in Vietnam (in terms of its development) it could be argued that women's transnational connections with Vietnam are shaped by gendered expectations surrounding the transmission of Vietnamese culture. This could be understood as an outcome of gendered processes which position women as the bearers of culture (Yuval-Davis 1997), (as seen by the encouragement of their family members). The female participants make significant cultural and personal investments and 
develop competence in Vietnamese language in order to achieve the status of Vietnamese authenticity. This may also be seen to be shaped by traditional Vietnamese expectations of feminine ideals, which include the attributes of 'industriousness' and 'good communication skills' (Nguyen 2013; 2-4). However, while Ong (1999) has observed that transnationalism can often accentuate issues of gender inequality for women in the country of origin. In these narratives there is no significant attempt to reflect critically upon differing gender roles between Britain and Vietnam (even though observations of the poor treatment of women by new male Vietnamese migrants in the UK are made elsewhere in these narratives). Instead, what is notable is the appeal to 'help out' and get involved with the community in Vietnam rather than with the local community in London, signaling the importance of the presentation of an authentic Vietnamese self over issues of gender equality.

By comparison, women from South Vietnamese families tended to be equally active in their transnational links but engaged instead in other diaspora networks in the USA, Australia and France through specific transnational diaspora networks such as the VPS (Vietnamese Professional Society). While not tending to visit Vietnam as frequently as North Vietnamese participants, they contributed from a distance instead, through involvement with charities often through local Vietnamese Catholic Churches which send money back to Vietnam (see Barber 2015 and Espiritu and Tran 2002). These different trends are illustrative of broader ideological and family differences, whereby South Vietnamese families were more likely to hold anti-communist views (supported in the wider disaspora) whereas North Vietnamese families were more likely to migrate for economic reasons and maintained closer ties to family in Vietnam (see James 2011).

\section{British-born Vietnamese men's narratives of visits to Vietnam}


Visits to Vietnam were experienced and narrated differently by British-born

Vietnamese men by comparison to the women. Notably, young men seem to exemplify more symbolic forms of transnationalism and made less personal investments during their visits. Nevertheless 'return visits' still acted as 'global magnified moments', but often through a sense of their social class difference in Vietnam, combined with a sense of trepidation about returning to Vietnam due to potential social and physical threats ${ }^{8}$ :

As soon as I set foot in Vietnam they can tell the difference immediately, they are saying 'ah he is a foreigner' or something. Yeah, and you know I get looked at and that and I can hear them talking (..) but it feels good! It feels like I am noticed for some reason! For being nothing! I am like a celebrity, I am doing nothing!

(David 19, Drama Student, North Vietnamese, East London)

Well, firstly when they see you come from the UK they think you are rich and everything and then slowly they start to see you as more Vietnamese and treat us as normal like other people over there. But there is still crime and stuff like that over there, they are still not fully developed as a country. There are warnings about people around at night time, um, well its poverty really - poor people just take [your] money and they just want to get something for themselves.

(Khanh, 18, Estate Agent trainee, North Vietnamese, South East London)

Ahh I'm terrified about going to Vietnam, because obviously not speaking Vietnamese, I know that is going to be a factor and I know that people judge me for it. But I am just going to try and make up for it, try to get stuck in and have fun and stuff 
like that. I am just going to see what it is like to be honest, because I have never been to Vietnam. So it will be a massive culture shock as I am told by my uncle but err, I am a bit nervous about it. But I guess I will get a little insight into like umm what it is like to be Vietnamese really.

(Minh, 18, Art Foundation student, North Vietnamese)

In the narratives above a range of different issues emerge that relate back to young people's position in London versus those in Vietnam. Notably, the young North Vietnamese men above came from more working class families in London and their visits to Vietnam were experienced with more difficulty given their position in the global hierarchy of patriarchy (Hoang 2015). These men often foreground both the positive and negative effects of social class differences by defining Vietnam as a developing country, where poverty and visceral displays of poor standards of living were common place (a similar process is observed by Kibria 2002 and Louie 2004). Although being perceived in certain Vietnamese 'street' contexts as 'different' and visible can be positive due to the more powerful social class status that they embody as affluent Viet Kieu, however the experience is also disempowering due to their limited linguistic and cultural competence whilst being a visible target of crime. Likewise, their more elevated social class position did not seem to lead to an acceptance among the middle- or upper-class local Vietnamese either. As Carruthers (2002), Chan (2011) and Hoang (2015) have shown the Viet Kieu are often perceived with some distain by more affluent local Vietnamese due to their embodiment or representation of Western power regimes (and its relative economic decline in recent years with Asian ascendency (see Hoang 2015)). In some cases, this paradoxical positioning was experienced negatively in Vietnam leading male participants to shift their transnational engagement towards sending remittances 
as a form of transnational identity practice. For example, Paul, a 27 year old North Vietnamese participant explains being 'horrified' by how people lived in Vietnam and particularly the level of poverty visible on the street noting; 'I don't like to go back too often, there is too much poverty and it gets me down'. Instead he bought a house for his extended relatives which helped him to adjust his sense of transnational participation in the homeland.

Social class, family regional origins, as well as gender, shaped British-born Vietnamese men's engagement with Vietnam in other ways. In contrast to the female participants, men were more likely to conceive of returning to Vietnam for very short trips such as holidays. For example, Duc a well-educated, well-paid professional from a South Vietnamese family discusses more fleeting and superficial returns to Vietnam:

The first time I went to Vietnam I was 2004. I don't remember much about it so basically it was like a tourist going there. Generally, I go for a week at a time, whereas most people I know go for like 7 weeks at a time. I generally go for a week at a time and if I do go these days it is generally I tend to squeeze it in to a business meeting. If I've got a business meeting in Singapore or something I'll take 3 days off as a holiday and I squeeze it in, I'll go to Saigon or something. But yeah it is a nice place, you can go and relax and everything, funnily enough I don't actually like going there as much as other countries in South East Asia. Umm Bangkok is more a place that I much enjoy sort of with the club scene and the night life etc where as Vietnam is slowly developing. When I go back there I feel like a tourist the only thing is that at least I can speak the lingo, I can speak the local language but they can spot straight away that I am not a local Vietnamese. That is the only thing I feel, I don't feel any links to it, you know, I don't feel any emotional attachment, I don't recognise the streets or the buildings. 
(Duc, Male, 30 Banking Executive, South Vietnamese)

Here the social class dynamics are central in shaping the relationship Duc has with Vietnam enabling him to 'squeeze' in a trip to Vietnam relatively easily but without having to engage in a negotiation of insider/outsider identities with the local Vietnamese. Unlike the previous participants, Duc, through his upper middle-class positioning in the UK, seems more in line with the positioning of the 'transnational Asian business man' (see Hoang 2015) in Vietnam according to competing global hierarchies of race, social class and nation, and is thus able to avoid some of the scrutiny experienced by other more working-class London-based Viet Kieu. Although Duc can speak Vietnamese well (unlike other participants discussed here, like Jenny and Minh), this does not seem to bring him any special privileges beyond the 'average tourist'. Instead, his greater sense of connection to other Southeast Asian cities like Bangkok, seems to place him within more upwardly mobile 'cosmopolitan' categories within international social hierarchies of race and social class (see Anthias 2013, Carruthers 2002). This process is also observable in the narrative of Mark, another more affluent, middle-class South Vietnamese participant:

I guess certainly in some sense it is always going to be more than a holiday destination but in the same time it was kind of like that cos previously I had no sense of being Vietnamese... so it was quite surprising when I got there that it did bring out some things about being Vietnamese and being proud about who I am, from that point of view, that was interesting! I think also having been born there, there was a familiarity; it wasn't like going somewhere completely new somehow, somehow! I mean I didn’t know my way around obviously at all but somehow it was familiar, sort of smells I think and sounds, I just felt very comfortable there, which was great! 
Sensuous experiences of the homeland often become very powerful especially for those who do not have more concrete connections with the homeland community, and represent a form of symbolic transnationalism. Mark reflects back upon a more distant or intangible sense of belonging in Vietnam during his first visit to Vietnam in his late teen years. This notion of sensuousness and the intangible sense of returning to the 'homeland' have also been explored in relation to the American Greek diaspora (Christou 2006). Mark’s describes his diaspora bond at a more embodied and emotional level rather than through specific networks and interactions (as described by female participants). This illustrates the range of ways in which visits to Vietnam are used or have enabled participants to develop alternative 'knowledges' of Vietnam and claims to a Vietnamese identity, independent of those based at the 'local' community level. Similar functions of visits have also been described by Delany (1990) as a 'secular pilgrimage', which enabled Turkish returnees to 'touch the foundation of their being' 'renew their identity' and give them 'dignity' (Delany 1990; 525).

Trips back to Vietnam for the first time often held the hope of offering a way of 'resolving' identity issues and issues around the search and achievement of authenticity, as discussed, in relation to young Vietnamese women earlier in this article. Visits to the 'ancestral land' often emerge from a sense of displacement and difficulty with assimilation into the country of settlement and thus are expected to be an opportunity to explore the origin of differences, and perhaps validate them (Maruyama and Stronza 2010). This was particularly pertinent for identity claims made in British society:

Because I grew up in Britain, I am really Westernised so I need to be reattached with my own [people] sort of thing, I feel that just being here I have lost my identity. 
Obviously, I know who I am, obviously I am in touch with my cultural side, obviously I know that I am a Buddhist, so I know where my parents come from, their culture, background, their experiences and obviously they remind me that I am Vietnamese but my parents also say to me that 'you are British', because I was born here. But growing up in Britain you lose that sense of having British identity because of experiences of racism and not feeling like you belong. But because I am going back to Vietnam in two weeks time to meet my whole family, it should sort that all out. When I go to Vietnam and I come back, I'll be able to say I'm a Vietnamese, I'll get my identity, I'll probably feel more proud to say that I am a British-born Vietnamese.

(Luke, 24, South Vietnamese, Financial Executive)

However, when Luke returned from his trip to Vietnam, it had not straightforwardly 'sorted his identity out' but instead he reported finding himself in more of a quandary over where he belonged and his sense of a Vietnamese identity. He had discovered more differences than similarities, particularly in those related to social class; being alerted to the poverty in Vietnam and the conditions of a developing country. While Luke refers to his identity as being responsible for providing his sense of well-being, like other male participants, he did not get the sense of becoming 'one of us really' nor of authenticating a Vietnamese identity after visiting Vietnam. Again, this could be explained by the differential level of investment made by male and female participants, with greater expectations placed upon women to 'learn' the culture and language. Also, it could be argued that the more one feels excluded in the Vietnamese community in Britain, the greater the hopes and desires to authenticate one's Vietnamese identity in visiting the 'homeland'. Notably, these men seem to experience a 
form of unexpected 'social class displacement' whereby their anticipated Viet Kieu status in Vietnam did not lead to a better sense of accommodation in the homeland.

\section{Discussion and conclusion}

This article has contributed to the burgeoning literature on the international Vietnamese diaspora and the practice of 'return' visits by exploring the experiences of the British-born Vietnamese. While the participants in this research have not returned to Vietnam permanently, as seen in other research among the Australian diaspora (Carruthers 2002) and the American diaspora (Thai 2011, 2014), instead this research has shown the different ways in which men and women from the British Vietnamese diaspora contemplate their more temporary 'return' visits and their place in relation to the 'homeland', as a process of ethnic authentification. Drawing upon the notions of 'return visits as global magnified moments' (Thai 2011) and 'symbolic transnationalism' (Espiritu and Tran 2002) this article has explored the ways in which return visits can be used as a form of diasporic cultural capital experienced and used in narratives of belonging and ethnic authenticity. However, the paradox of social class displacement has rendered this process somewhat 'arrested'. These have been a product of the relations between Vietnam, Britain and the British Vietnamese community in a number of ways:

Firstly, the welcoming policy of the Vietnamese state towards its diaspora has become more relaxed in recent years has meant that return visits home is still a relatively recent practice (Phuong 2000). Among the British Vietnamese this has also been a relatively new practice as many did not have the money to return back until more recently (now as adults the younger generation can fund their own air tickets 'home'). The differences between the North and South Vietnamese participants had also shaped prospective visits to Vietnam, 
as North Vietnamese participants were more likely to return as they were ethnic-Chinese fleeing persecution after the Chinese invasion of Vietnam rather than being opposed to the Vietnamese government by comparison to those from South Vietnamese families which confronted additional ideological barriers to return. At the same time, the perceived lack of provision for inclusion and participation in the London community has led the younger generation to search for other sources of cultural and ethnic validation in Vietnam and the broader diaspora. While the British approach towards multiculturalism and its model of cultural pluralism should, in theory, enable the British Vietnamese to adopt a sense of belonging and inclusion in London, debates on British multiculturalism in recent years have tended to overlook less visible and more silent minorities and focus on more visible groups (Vertovec 2007, Enneli et al 2005, Parker 2000). As a numerically small minority, the Vietnamese communities have tended to remain culturally invisible, which may in part be responsible for the need to search for identity through return visits to Vietnam.

Second, this article has traced the affects of gender, social class and migratory origins upon experiences and perceptions of return visits. Distinctions between young women and men's narratives and by North and South Vietnamese backgrounds, demonstrate the complex gender and social class distinctions these ensue. While participants from North Vietnamese families narrate more direct experiences of visiting Vietnam, those from South Vietnamese families maintain more distant relationship approximating 'visiting as a tourist'. These experiences are further classed; those from South Vietnamese families are more likely to come from professional family backgrounds and have more cultural and material resources with which to negotiate their relationship with Vietnam and Britain, while those from North Vietnamese backgrounds in Britain were traditionally less socio-economically prosperous and relied more upon family relationships in Vietnam to negotiate their return. Women from all backgrounds appear to be more dynamically active in their engagement with Vietnam. 
This latter point can be argued as serving gendered expectations about women gaining cultural competences and linguistic skills as ‘bearers of culture' (Yuval-Davis 1997). Men's experiences were more likely to be shaped by expectations of socio-economic power and related concepts of masculinity which challenges and arrests the achievement of ethnic authenticity during their visits to Vietnam. This finding is corroborated by Thai's (2014) findings that forms of socio-economic power is linked to constructions of masculinity among the returning overseas Vietnamese (also see Hoang 2015 and Carruthers 2002). This point reinforces the argument made by Fresnoza-Flot and Shinozaki (forthcoming) for treating gender and class not as isolated categories or variables but as 'social relationship[s] entailing a power hierarchy'(p14), in which they interact with other categories of difference within a specific 'context' (p15).

Thirdly, while an international expenditure cascade demonstrated by Thai (2014) has shown how low-wage American Vietnamese return to Vietnam with a renewed social status (since they can reinvent their social class identity and masculinities based upon ideas in Vietnam about the prosperous and 'successful' Viet Kieu), this paper has shown how a reverse process appears to be working for British-born Vietnamese men who invest more symbolically in their relations with Vietnam, which in turn serve the purpose of validating their identity as Vietnamese in Britain (rather than in Vietnam) thus leading to a more arrested achievement of ethnic authentification. A form of social class displacement takes place which seems to challenge their initial expectations. These differences might be explained by socio-demographic differences in addition to those of national and historical contexts as the participants in my study are all born, raised and educated in Britain, they are younger and have all had an uninterrupted education with recognised qualifications. As part of the British-born generation it seems incumbent upon them to prove a Vietnamese authenticity by comparison to the 1.5 generation migrants found in Thai's (2014) study to 
whom issues of social class status appear a more central concern. This suggests that place of birth and where one is raised may have a significant impact upon attitudes towards the 'homeland'. The role of gender in these formulations is also significant; for the British-born Vietnamese men, returning to Vietnam did not enable a 'restored' or 'achieved' masculinity, rather it seem to present a challenge to it, in reverse, it might even be possible to say that the Vietnamese women in my sample were able to achieve an enhanced sense of Vietnamese femininity in Britain as their cultural familiarity with Vietnamese culture and language might have worked to improve their status as an authentic Vietnamese woman (Kibria 1997, Nguyen 2013) in Vietnam and in the London Vietnamese community.

\section{Notes}

1. This is based on those who 'wrote-in' as ethnic Vietnamese. This extends previous estimates which placed the population at between 55,000 and 65,000 in the UK (IOM 2006). 2. While these four distinctions ares a useful way of understanding the trajectories of different groups within the Vietnamese community in Britain. It is also important to understand the complexity and emerging nature of group identities such as age, background and situation of different refugees.

3. I define my participants as British-born Vietnamese to refer specifically to the participants who were born in Britain and spent the majority of their life and their formative years in Britain. The use of this term will also avoid some of the conceptual problems with the concept of 'second generation'.

4. All interviews were taped with consent and fully transcribed by the author. Research participants were given pseudonyms to protect their identity and ensure data confidentiality. 5. For a discussion of those who focused primarily on trans-local ties see Barber (2015). 
6. However, Carruthers (2002) has shown how the national Vietnamese are very discerning of the Viet Kieu and the participants in his study were not able to easily pass as local Vietnamese.

7. This example of 'going native' chimes with Carruthers' (2002) research which discusses how Viet Kieu were able to pass and at other times were not able to pass depending upon context.

8. Women also received these comments sometimes but dealt with it differently, tending not to acknowledge them to the same extent as men.

\section{References}

Alumkal, A. W. 1999. "Preserving Patriarchy: Assimilation, Gender Norms, and SecondGeneration Korean American Evangelicals.” Qualitative Sociology 22: 127-140.

Anthias, F. 2013. "Hierarchies of Social Location, Class and Intersectionality: Towards a Translocational Frame" International Sociology 28 (1): 121-138.

Bagwell, S. 2015. “Transnational Entrepreneurship amongst Vietnamese Businesses in London". Journal of Ethnic and Migration Studies 41(2): 329-349.

Bagwell, S. 2008. "Transnational Family Networks and Ethnic Minority Business Development. The Case of Vietnamese Nail-Shops in the UK". International Journal of Entrepreneurial Behaviour and Research 14 (6): 377-394.

Barber, T. 2015.Oriental Identities in Super-Diverse Britain: Young Vietnamese in London Basingstoke: Palgrave Macmillan. 
Basu, P. 2004. "My Own Island Home: The Orkney Homecoming”. Journal of Material Culture 9 (1): 27-42.

Bradley, H. 1996. Fractured Identities: Changing Patterns of Inequality. Cambridge: Polity Press.

Brah, A. 1996. Cartographies of Diaspora: contesting identities. London: Routledge.

Bourdieu, P. 1983. "The Forms of Capital." In Handbook of Theory and Research for the Sociology of Education, edited by J. Richardson, 241-258. New York: Greenwood Press.

Caglar. A. 1995. "German Turks in Berlin: Social Exclusion and Strategies for Social Mobility. New Community 21: 309-323.

Carruthers, A. 2002. "The Accumulation of National Belonging in Transnational Fields: Ways of Being at Home in Vietnam" Identities: Global Studies in Culture and Power 9 (4): 423-444.

Chan, Y. W. 2013. "Hybrid Diaspora and Identity-Laundering: A Study of the Return Overseas Chinese Vietnamese in Vietnam.” Asian Ethnicity 14(4): 525-541.

Chan, Y. W., and T.L.T. Tran. 2011. "Recycling Migration and Changing Nationalisms: Vietnamese Return Diaspora and Reconstruction of the Vietnamese Nationhood." Journal of Ethnic and Migration Studies 37 (7): 1101-1117.

Christou, A. 2006. "Deciphering Diaspora - Translating Transnationalism: Family Dynamics, Identity Constructions and the Legacy of 'Home' in Second-Generation Greek-American Return Migration.” Journal of Ethnic and Racial Studies 29 (6): 1040-1056.

Christou, A., and R. King. 2010. “Imagining 'Home': Diasporic Landscapes of the GreekGerman Second Generation." Geoforum 41 (4): 638-646. 
Cohen, E. 1979. "A Phenomenology of Tourist Experience." The Journal of the British Association 13: 179-201.

Cohen, E. 1974. "Who is a Tourist?: Conceptual Clarification." Sociological Review 22: 527555.

Dalglish, C. 1989. Refugees from Vietnam. London: Macmillan.

Delaney, C. 1990. “The 'Hajj': Sacred and Secular.” American Ethnologist 17 (3): 513-530.

Duke, K., and T. Marshall. 1995. Vietnamese Refugees Since 1982. London: HMSO.

Duval, D. 2004. “Conceptualizing Return Visits: A Transnational Perspective.” In Tourism, Diasporas, and Space, edited by T. Coles, and D.J. Timothy, 50-61. London: Routledge.

Espiritu, Y. L and T. Tran. 2002. “'Viet Nam, Nuoc Toi’: Vietnamese Americans and Transnationalism." In The Changing Face of Home: The Transnational Lives of the Second Generation, edited by P. Levitt, and M.C. Waters, 367-398. New York: Russell Sage Foundation.

Fresnoza-Flot, A., and K. Shinozaki. Forthcoming. "Introduction. Transnational Perspectives on Intersecting Experiences: Gender, Social Class and Generation among Southeast Asian Migrants and Their Families." Journal of Ethnic and Migration Studies. Special Issue on Transnational Perspectives on Intersecting Experiences: Gender, Social Class and Generation among Southeast Asian Migrants and Their Families, edited by K. Shinozaki and A. Fresnoza-Flot.

IOM. 2006. The Vietnamese Community in Britain. Home Office.

James, S. 2011. "Vietnamese Londoners: Transnational identities Through Community Networks" PhD diss., University of London. 
Kasinitz P, M. Waters, J. Mollenkopf, and M. Anil. 2002. "Transnationalism and the Children of Immigrants in Contemporary New York". In The Changing Face of Home: The Transnational Lives of the Second Generation, edited by M. C Waters, and P. Levitt, 96-122. New York: Russell Sage Foundation Press.

Kibira, N. 2002. Becoming Asian American: Second-Generation Chinese and Korean American Identities. Baltimore: Johns Hopkins University Press.

Levitt, P. 2009. "Routes and Roots: Understanding the Lives of the Second Generation Transnationally" Journal of Ethnic and Migration Studies 35(7): 1225- 1242.

Levitt P, and N. Glick Schiller. 2004. "Conceptualizing Simultaneity: A Transnational Social Field Perspective on Society.” International Migration Review 38: 1002-1039.

Levitt, P., and M. Waters. 2002. "Introduction.” In The Changing Face of Home: The Transnational Lives of the Second Generation, 1-32. New York: Russell Sage Foundation Press.

Louie, V. 2006. "Growing Up Ethnic in Transnational Worlds: Identities among Second Generation Chinese and Dominicans." Identities 13 (3): 363-94.

Maruyama, N., and Stronza, A. 2010. "Roots Tourism of Chinese Americans" Ethnology 49 (1): $23-44$.

Office for National Statistics (ONS). 2011. 2011 Census: Aggregate Data (England and Wales; accessed May 21st, 2014). UK Data Service Census Support. http://infuse.mimas.ac.uk

Ong, A. 1999. Flexible Citizenship: The Cultural Logic of Transnationality. Duke University Press. 
Parker, D. 1995. Through Different Eyes: The Cultural Identities of Young Chinese People in Britain. Aldershot: Avebury.

Parker, D. 2000. “The Chinese Takeaway and the Diasporic Habitus: Space, Time and Power Geometrics.” In Un/settled Multiculturalisms, edited by B. Hesse, 73-95. London: Zed Books.

Pham, A. T. 2010. “The Returning Diaspora: Analysing overseas Vietnamese (Viet kieu) Contributions toward Vietnam's Economic Growth" DEPOCENWP Working Paper Series, no. 20 .

Pluss, C. 2005. "Constructing Globalized Ethnicity: Migrants from India in Hong Kong." International Sociology 20: 201-224.

Raj, D.S. 2003. Where Are You From?: Middle-Class Migrants in the Modern World. Berkeley: University of California Press.

Sims, J. 2007. The Vietnamese Community in Great Britain: Thirty Years On A Runnymede Community Study. London: Runnymede.

Thai, H. C. 2014. Insufficient Funds: The Culture of Money in Low-Wage Transnational Families. Stanford: Stanford University Press.

Thai, H. C. 2011. "Homeland Visits: Transnational Magnified Moments among Low-Wage Immigrant Men.” In At the Heart of Work and Family: Engaging the Ideas of Arlie Russell Hochschild, edited by A. Garey, and K. Hansen. New Jersey: Rutgers University Press.

Thomas, M. 1999. Dreams in the Shadows: Vietnamese-Australian Lives in Transition. St. Leonards, N.S.W: Allen \& Unwin.

Weber, M. 1946. “Class, Status, Party.” In From Max Weber: Essays in Sociology, edited by H. H. Girth, and C. Wright Mills, 180-195. New York: Oxford University. 
Wengraf, T. 2001. Qualitative Research Interviewing: Biographic Narrative and SemiStructured Methods. Thousand Oaks, CA: Sage.

Viviani, N. 1996. The Indochinese in Australia 1975-1996: From Burnt Boats to Barbeques. Melbourne: Oxford University Press,

Yuval-Davis, N. 1997. Gender and Nation. Sage: London. 